\title{
In vitro Axillary Shoot Regeneration and Direct Protocorm-like Body Induction from Axenic Shoot Tips of Doritis pulcherrima Lindl.
}

\section{Tustu Mondal, Sumana Aditya and Nirmalya Banerjee*}

Laboratory of Cytogenetics and Plant Biotechnology, Department of Botany, Visva-Bharati University, Santiniketan-731235, West Bengal, India

Key words: Axillary shoot, Regeneration, Direct Protocorm-like body, Axenic shoot, Doritis pulcherrima

\begin{abstract}
An efficient protocol for in vitro propagation of an important ornamental terrestrial orchid, Doritis pulcherima Lindl. through axillary shoot and direct protocorm-like body (PLB) formation from shoot tip explants derived from sixmonth-old axenic seedlings has been described. Shoot tips were cultured on modified nutrient medium of Knudson's C supplemented with $0.1 \%$ peptone and combination of various concentrations of NAA and BAP. The effect of NAA and BAP on axillary shoot formation, protocorm-like body induction and root regeneration from the explants was significant. The highest frequency of axillary shoot formation was recorded in the medium containing $2 \mathrm{mg} / \mathrm{l}$ BAP and the PLB production was higher in the medium containing $2 \mathrm{mg} / \mathrm{l}$ NAA. A higher concentration of BAP showed inhibitory effects on the axillary shoot formation and PLB induction. Efficient root regeneration was observed in low concentration of NAA. However, the profuse root formation was common in the PGR free medium. Rooted plantlets were hardened successfully through the stepwise acclimation protocol and platelets were finally established in the potting mixture containing small pieces of dead tree bark of mango, charcoal pieces and broken bricks in $1: 2: 1$ ratio.
\end{abstract}

\section{Introduction}

Doritis pulcherrima Lindl. is a sympodial, terrrestrial orchid belonging to the family Orchidaceae, subfamily Epidendroideae, and tribe Vandeae. The genus Doritis has a wide distribution, ranging from the Himalayas of Northern India, through Thailand and Burma, to Malaysia and Indonesia (Treuscher 1977). It

*Author for correspondence: <nirmalya_b@rediffmail.com>. 
bears beautiful flowers and is a valuable material for the orchid hybridization. D. pulcherrima, synonymous with Phalaenopsis pulcherrima (Lindl.) J. J. Smith (Sweet 1980, Christenson 1995), has been used extensively in breeding with Phalaenopsis to produce floriculturally important hybrid Doritaenopsis superior cultivars. Although hybridization has long been practiced with this plant species for breeding superior cultivars, available information about the micropropagation of Doritis is relatively meager.

Orchid requires a combination of multiplicity of factor for the continued reproduction in nature. The propagation of orchids through sexual means is a very slow process as their seeds lack endosperm and require the fungal association for germination in nature. The fungus is believed to augment the carbohydrate, auxin and vitamin transport in the orchid (Arditti et al. 1982). Orchids are highly heterozygous and their vegetative propagation through division of clumps of rhizomes, bulbs or by the rooting of off shoots requires a long time. Moreover, it is extremely difficult to generate the desired number of plants. It is, therefore, critical to take initiative for mass propagation of orchids and subsequently their successful establishment in nature. Thus, tissue culture technique is considered as a potent alternative method for mass scale propagation of these orchids.

Shoot tip culture in sympodial orchids is an efficient system for the production of large numbers of plantlets in a short period of time (Chug et al. 2009). Propagation of orchids through shoot tip culture has been successful in Anacamptis, Anoectochilus, Arudina, Cymbidium, Dendrobium, Paphiopedilum, Phaius, Phalaenopsis, Vanda and Vanilla (Morel 1970, Huang 1988, Nagaraju and Parthasarathy 1995, Devi et al. 1997, Seeni and Latha (2000), Roy and Banerjee (2003), Subramanium and Taha (2003), Ket et al. (2004), Kalimuthu et al. (2006), Roy et al. (2007). A few genera such as Vanda (Seeni and Latha 2000), Cymbidium (Subramaniam and Taha 2003), and Dendrobium (Roy et al. 2007) are reported to be the best orchids in inducing PLBs by shoot tip culture. The aim of the present study is to develop a suitable protocol for micropropagation of D. pulcherrima from shoot tips and to elucidate the impact of exogenous cytokinin and auxin on the rate of shoot elongation, axillary branching, PLB formation and root induction.

\section{Materials and Methods}

The material used for in the present investigation was small axenic shoot tips of 2 - $4 \mathrm{~mm}$ length from six-month-old seedlings that have been raised in vitro through asymbiotic seed culture of D. pulcherrima. 
All inorganic macro- and micro-salts, iron-EDTA, sucrose, and potassium iodide were procured from Sisco Research Laboratory (SRL), Mumbai, India. The solidifying agent agar and peptone were purchased from Merck Ltd., Mumbai, India. BAP and NAA were procured from Sigma Chemicals Co., St Louis, USA.

In the present investigation, the culture medium used was modified nutrient solution of Knudson's C (1946) supplemented with or without various concentrations and combinations of BAP and NAA to assess the effect of PGR on PLB formation, shoot multiplication and rooting of D. pulcherimma Lindl. The medium was supplemented with $2 \%$ sucrose and $0.1 \%$ peptone. The original iron source was replaced with iron-EDTA of MS and the media were solidified with $0.8 \% \mathrm{w} / \mathrm{v}$ agar. The $\mathrm{pH}$ of the media was adjusted to 5.2 prior to autoclaving at $121^{\circ} \mathrm{C}$ for $20 \mathrm{~min}$.

For culture initiation, 2 - $4 \mathrm{~mm}$ long shoot tips were excised aseptically and transferred to Knudson's C (KC) basal media and also on to KC media supplemented with various concentrations and combinations of BAP (1.0 - 4.0 $\mathrm{mg} / \mathrm{l})$ and NAA (1.0 and $2.0 \mathrm{mg} / \mathrm{l})$. The experiment was planned with a total 12 treatments having five replicates for each with ten explants for each replica.

After inoculation, the cultures were incubated at $25 \pm 2{ }^{\circ} \mathrm{C}$ with $14 \mathrm{hrs}$ photoperiod of 3000 lux light intensity. The observations were recorded at regular intervals of one week up to the eighth weeks.

After three - four weeks of culture initiation, shoot tips exhibited either axillary shoot formation or adventitious PLB formation without callusing. In histological studies hand sections through suitable explants were made, mounted in $10 \%$ glycerin solution and observed under a binocular microscope Olympus $\mathrm{CH}-30$. Rootless axillary shoots developed in all the tested media except in KC with NAA $2.0 \mathrm{mg} / \mathrm{l}$ and BAP $4 \mathrm{mg} / \mathrm{l}$. Later rooting was achieved in the treatments devoid of BAP. In general, PLB production was observed in all the treatments.

For the induction of roots, regenerated single shoots were cultured both on $\mathrm{KC}+$ peptone and KC media supplemented with low concentrations of NAA (0.5 $-1 \mathrm{mg} / \mathrm{l})$. The cultures were maintained for induction and the ramification of roots.

The regenerated rooted plantlets were further subjected to ex vitro hardening. The plantlets were taken out from the culture vials and were washed thoroughly under running tap water to remove the traces of adhering agar. Those were then treated with $0.1 \%(\mathrm{w} / \mathrm{v})$ bavistin (fungicide) solution and again washed with water. The rooted plantlets were transferred to the potting mixture containing small pieces of dead tree bark (mango), charcoal pieces and broken 
bricks in $1: 2: 1$ ratio. The plants were totally covered with plastic bags initially to maintain humidity. Plants became acclimated to a reduced relative humidity by gradually removing the plastic cover and then, were completely uncovered and finally hardened to greenhouse conditions.

Somatic chromosomes were studied from actively growing root tips. Excised root tips were split longitudinally and the root caps and velamen tissues were carefully removed with a sharp scalpel. Root tips were pretreated with a mixture of saturated solution of para-dichloro benzene (PDB) and $2 \mathrm{~m}$ M 8-hydroxyquinoline $(1: 1)$ for $4 \mathrm{~h}$ at $18^{\circ} \mathrm{C}$, fixed in modified Carnoy's fluid (ethanol: chloroform: glacial acetic $=2: 1: 1)$ at $4^{\circ} \mathrm{C}$ for $24 \mathrm{~h}$, hydrolyzed in $1(\mathrm{~N}) \mathrm{HCl}$ for 10 min at $60^{\circ} \mathrm{C}$, stained in $2 \%$ aceto-orcein solution for $2 \mathrm{~h}$ and finally squashed in 45 $\%$ acetic acid.

All observed data were analyzed by one-way ANOVA test, followed by the Duncan's multiple range comparison at 0.05 significance level using SPSS (version 16) software package. Statistical analyses were performed on the arcsine transformed values of the data presented in Tables 1 and 2.

\section{Results and Discussion}

In the present investigation, two plant growth regulators were used either individually or in various combinations to fortify $\mathrm{KC}$ basal media for culturing shoot tips of D. pulcherrima. Depending upon the chemical composition of the media, cultured shoot tips followed two different pathways of growth and morphogenesis. In the first route, multiple shoots regenerated on explant surface through direct axillary shoot bud proliferation; and in the second pathway plantlets originated via PLB formation. In most of the cases, responses were directly observed from the meristematic dome of the cultured shoot tips. Formation of axillary shoots (Fig. 1A) and direct PLBs (Fig. 1B) from cultured shoot tips were initiated after 15 - 30 days which proliferated further for another three - four weeks.

Initially all explants swelled with no intervening callus formation. Necrosis of the explants was commonly observed in all the treatments in varying amounts. The frequency of occurrence of necrosis in the explants was high in the medium supplemented with NAA (Table 2). Addition of increasing concentrations of BAP either individually or in combination with NAA in the medium lowered the rate of necrosis. Tissue blackening and necrosis of the explants have been frequently encountered in this study; necrosis might have caused by the oxidation of phenolic compounds by polyphenol oxidase present in the explants. It has been reported earlier that the addition of organic acids and frequent subculturing of the propagules exhibited satisfactory result (Morel 1974, 
Table 1. Effects of NAA and BAP in varying concentrations on in vitro response of shoot tips after 60 days of culture.

\begin{tabular}{|c|c|c|c|c|c|c|}
\hline \multirow[t]{2}{*}{$\begin{array}{l}\text { Culture } \\
\text { media }\end{array}$} & \multicolumn{2}{|c|}{$\begin{array}{l}\text { Plant growth } \\
\text { regulators } \\
(\mathrm{mg} / \mathrm{l})\end{array}$} & \multirow[t]{2}{*}{$\begin{array}{l}\text { Axillary shoot } \\
\text { forming } \\
\text { explants }(\%)\end{array}$} & \multirow{2}{*}{$\begin{array}{c}\text { No. of } \\
\text { shoots/ } \\
\text { responding } \\
\text { explants }\end{array}$} & \multirow[t]{2}{*}{$\begin{array}{l}\text { PLB forming } \\
\text { explants } \\
(\%)\end{array}$} & \multirow{2}{*}{$\begin{array}{l}\text { No. of PLB } \\
\text { per } \\
\text { responding } \\
\text { explants }\end{array}$} \\
\hline & NAA & BAP & & & & \\
\hline N0B0 & - & - & $12.82 \pm 9.2^{\mathrm{abc}}$ & $0.92 \pm 0.5^{\mathrm{ab}}$ & $16.67 \pm 2.4^{b c}$ & $1.23 \pm 0.1^{\mathrm{abc}}$ \\
\hline N0B1 & - & 1 & $39.68 \pm 8.8^{c}$ & $1 \pm 0^{\mathrm{b}}$ & $7.69 \pm 4.4^{\mathrm{abc}}$ & $0.67 \pm 0.3^{\mathrm{ab}}$ \\
\hline N0B2 & - & 2 & $45.48 \pm 13.6^{c}$ & $1.47 \pm 0.3^{b}$ & $7.51 \pm 4.4^{\mathrm{ab}}$ & $0.67 \pm 0.3^{\mathrm{ab}}$ \\
\hline N0B4 & - & 4 & $11.43 \pm 5.9 \mathrm{abc}$ & $0.67 \pm 0.3^{\mathrm{ab}}$ & $2.38 \pm 2.3^{a}$ & $0.33 \pm 0.3^{a}$ \\
\hline N1B0 & 1 & - & $19.44 \pm 10^{\mathrm{abc}}$ & $0.67 \pm 0.3^{\mathrm{ab}}$ & $19.23 \pm 8.4^{\mathrm{bc}}$ & $7.33 \pm 3.2^{\mathrm{d}}$ \\
\hline N1B1 & 1 & 1 & $20.97 \pm 8.3^{\mathrm{abc}}$ & $1.22 \pm 0.2^{\mathrm{b}}$ & $20.79 \pm 7.5^{\mathrm{bc}}$ & $3.833 \pm 1.6^{\mathrm{cd}}$ \\
\hline N1B2 & 1 & 2 & $28.04 \pm 3.2^{\mathrm{bc}}$ & $1.17 \pm 0.2^{\mathrm{b}}$ & $10.07 \pm 2.7^{\mathrm{abc}}$ & $1.17 \pm 0.2^{\mathrm{abc}}$ \\
\hline N1B4 & 1 & 4 & $5.56 \pm 5.5^{\mathrm{ab}}$ & $0.33 \pm 0.3^{\mathrm{ab}}$ & $4.94 \pm 2.5^{\mathrm{ab}}$ & $0.67 \pm 0.3^{\mathrm{ab}}$ \\
\hline N2B0 & 2 & - & $17.78 \pm 9.6^{\mathrm{abc}}$ & $0.67 \pm 0.3^{\mathrm{ab}}$ & $24.44 \pm 8^{c}$ & $1.83 \pm 0.3^{\mathrm{bc}}$ \\
\hline N2B1 & 2 & 1 & $15 \pm 7.6^{\mathrm{abc}}$ & $0.67 \pm 0.3^{\mathrm{ab}}$ & $7.17 \pm 0.3^{\mathrm{abc}}$ & $1 \pm 0^{\mathrm{ab}}$ \\
\hline N2B2 & 2 & 2 & $19.17 \pm 10.8^{\mathrm{abc}}$ & $0.89 \pm 0.5^{\mathrm{ab}}$ & $15.45 \pm 0.7^{b c}$ & $1.67 \pm 0.3^{\mathrm{abc}}$ \\
\hline N2B4 & 2 & 4 & $0 \pm 0^{a}$ & $0 \pm 0^{\mathrm{a}}$ & $4.94 \pm 2.5^{\mathrm{ab}}$ & $0.67 \pm 0.3^{\mathrm{ab}}$ \\
\hline
\end{tabular}

Data shown are the mean of five replicates. In each column, mean values followed by the same letter are not significantly different at the $0.05 \%$ level (DMRT).

Table 2. Effects of plant growth regulators on in vitro rooting of plantlets and necrosis of explants.

\begin{tabular}{|c|c|c|c|c|c|}
\hline \multirow[t]{2}{*}{$\begin{array}{l}\text { Culture } \\
\text { media }\end{array}$} & \multicolumn{2}{|c|}{$\begin{array}{c}\text { Plant growth regulators } \\
(\mathrm{mg} / \mathrm{l})\end{array}$} & \multirow{2}{*}{$\begin{array}{c}\text { Root } \\
\text { forming } \\
\text { plantlets }(\%)\end{array}$} & \multirow{2}{*}{$\begin{array}{c}\text { No. of } \\
\text { roots per } \\
\text { explant }\end{array}$} & \multirow{2}{*}{$\begin{array}{c}\text { Explant } \\
\text { necrosis } \\
(\%)\end{array}$} \\
\hline & NAA & BAP & & & \\
\hline NOB0 & - & - & $28.57 \pm 4.1^{c}$ & $1.83 \pm 0.4^{\mathrm{b}}$ & $24.44 \pm 4.4^{\mathrm{bc}}$ \\
\hline N0B1 & - & 1 & $0 \pm 0^{\mathrm{a}}$ & $0 \pm 0^{a}$ & $12.82 \pm 2.6^{\mathrm{abc}}$ \\
\hline N0B2 & - & 2 & $0 \pm 0^{\mathrm{a}}$ & $0 \pm 0^{a}$ & $7.7 \pm 4.4^{\mathrm{a}}$ \\
\hline N0B4 & - & 4 & $0 \pm 0^{a}$ & $0 \pm 0^{a}$ & $14.29 \pm 4.1^{\mathrm{abc}}$ \\
\hline N1B0 & 1 & - & $17.8 \pm 6.7^{\mathrm{b}}$ & $2.41 \pm 0.4^{\mathrm{c}}$ & $32.3 \pm 12.6^{c}$ \\
\hline N1B1 & 1 & 1 & $0 \pm 0^{\mathrm{a}}$ & $0 \pm 0^{a}$ & $20.32 \pm 3.6^{b c}$ \\
\hline N1B2 & 1 & 2 & $0 \pm 0^{\mathrm{a}}$ & $0 \pm 0^{\mathrm{a}}$ & $19.96 \pm 2.3^{b c}$ \\
\hline N1B4 & 1 & 4 & $0 \pm 0^{\mathrm{a}}$ & $0 \pm 0^{a}$ & $21.16 \pm 3.3^{b c}$ \\
\hline $\mathrm{N} 2 \mathrm{~B} 0$ & 2 & - & $24.44 \pm 2.2^{c}$ & $1.67 \pm 0.2^{b}$ & $28.57 \pm 4.1^{b c}$ \\
\hline N2B1 & 2 & 1 & $0 \pm 0^{a}$ & $0 \pm 0^{\mathrm{a}}$ & $21.32 \pm 3.9^{b c}$ \\
\hline N2B2 & 2 & 2 & $0 \pm 0^{\mathrm{a}}$ & $0 \pm 0^{\mathrm{a}}$ & $24.36 \pm 6.2^{b c}$ \\
\hline $\mathrm{N} 2 \mathrm{~B} 4$ & 2 & 4 & $0 \pm 0^{\mathrm{a}}$ & $0 \pm 0^{\mathrm{a}}$ & $12.27 \pm 2.6^{\mathrm{ab}}$ \\
\hline
\end{tabular}

Data shown are the mean of five replicates. In each column, mean values followed by the same letter are not significantly different at $0.05 \%$ level (DMRT). 
Ernst 1994). Specifically in orchids, oxidation of phenolics was reported to account for browning of explants followed by necrosis (Morel 1974, Vendrame and Maguire 2007).

In general, the type, concentration and combination of cytokinins play a key role in in vitro propagation of many orchid species (Arditti and Ernst 1993). In the present study, it was clearly observed that reduced concentrations of BAP ( 1 or 2 $\mathrm{mg} / \mathrm{l}$ ) resulted in the maximum axillary shoot formation (Fig. 1D). Furthermore, this response of BAP varied significantly $(\mathrm{p}<0.05)$ from the remaining treatments. However, the basal medium $+0.1 \%$ peptone as control failed to produce any significant effect on the axillary shoot formation. Among the different combinations tested in this study, NAA $(1 \mathrm{mg} / \mathrm{l})$ and BAP $(2 \mathrm{mg} / \mathrm{l})$

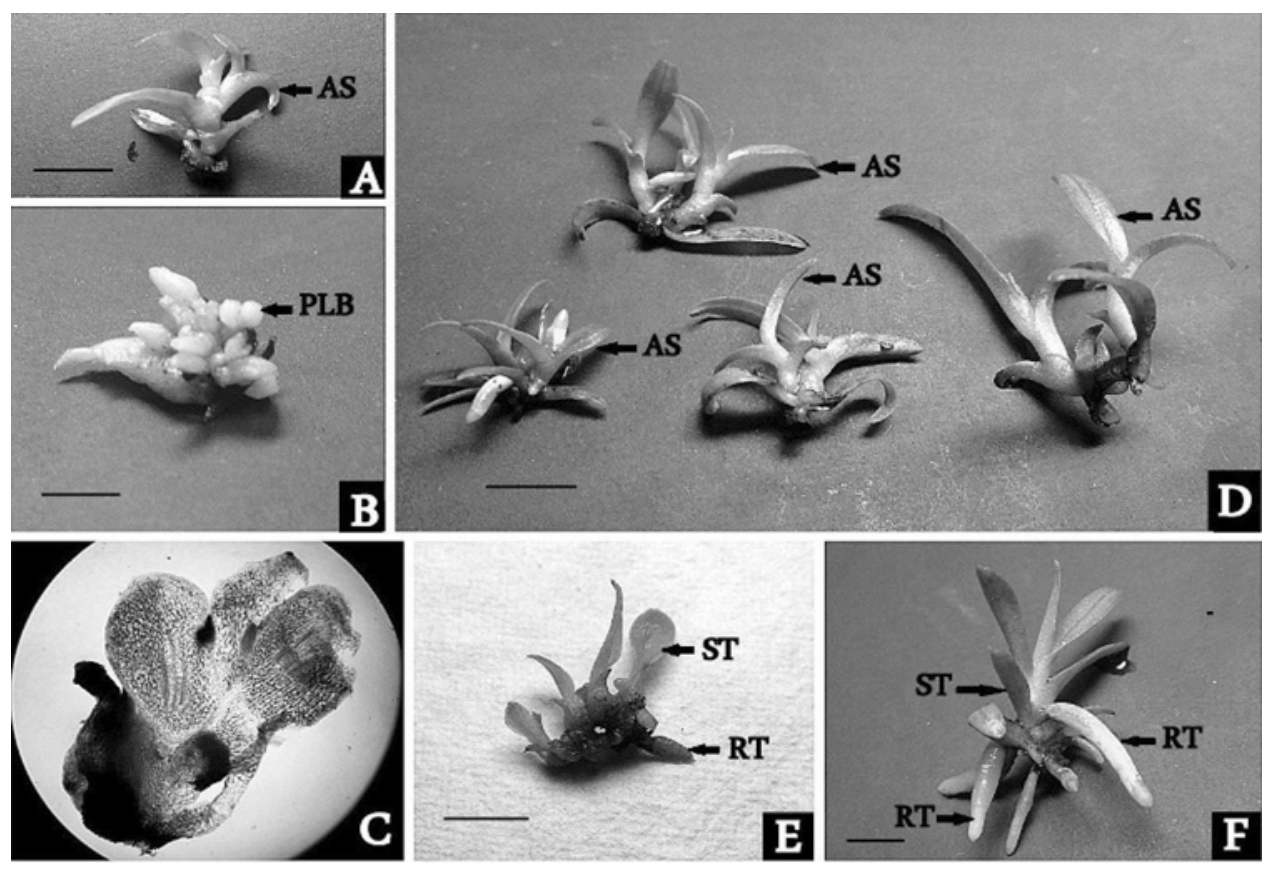

Fig. 1. In vitro multiplication and plant regeneration from shoot tips of Doritis pulcherrima: A. Initiation of axillary shoot (AS) after 25 - 30 days. B. Profuse multiplication through PLB formation after 20 - 25 days. C. Histological details of PLB formation from shoot tip explants. D. Development of healthy axillary shoots (AS) after $40-45$ days. E. Differentiation of shoots (St) and roots (Rt) from PLB. F. In vitro rooting of the regenerants with well-developed roots $(\mathrm{Rt})$. Bar $=1 \mathrm{~cm}$.

were found effective in shoot multiplication. High concentration of BAP and low concentration of NAA favored the induction of multiple shoots in Dendrobium fimbriatum (Rajkarnikar and Niraula 1994), in Cymbidium karnan (Chung et al. 1998), in Dendrobium orchid (Talukdar et al. 2003), in Aerides odorata 
(Pant and Gurung 2005) and in Dendrobium transparens (Sunitibala and Kishor 2009).

On the contrary, increased levels of BAP exhibited suppression of shoot proliferation as well as enhancement of shoot elongation in D. pulcherrima. Such findings are in agreement with those reported on the endangered terrestrial orchid Anoectochilus elatus (Sherif et al. 2012). The present study also indicated that exogenous auxin along with cytokinin suppressed the apical dominance, which led to the proliferation of axillary shoots. The combined NAA + BAP treatments increased the formation of shoots compared to BAP alone. Thus, the regeneration potential of explants was markedly influenced by their physiological status and chemical stimulus provided by the medium. The quality, quantity and the nature of growth regulators have a significant effect on the regeneration efficiency of shoot tip explants.
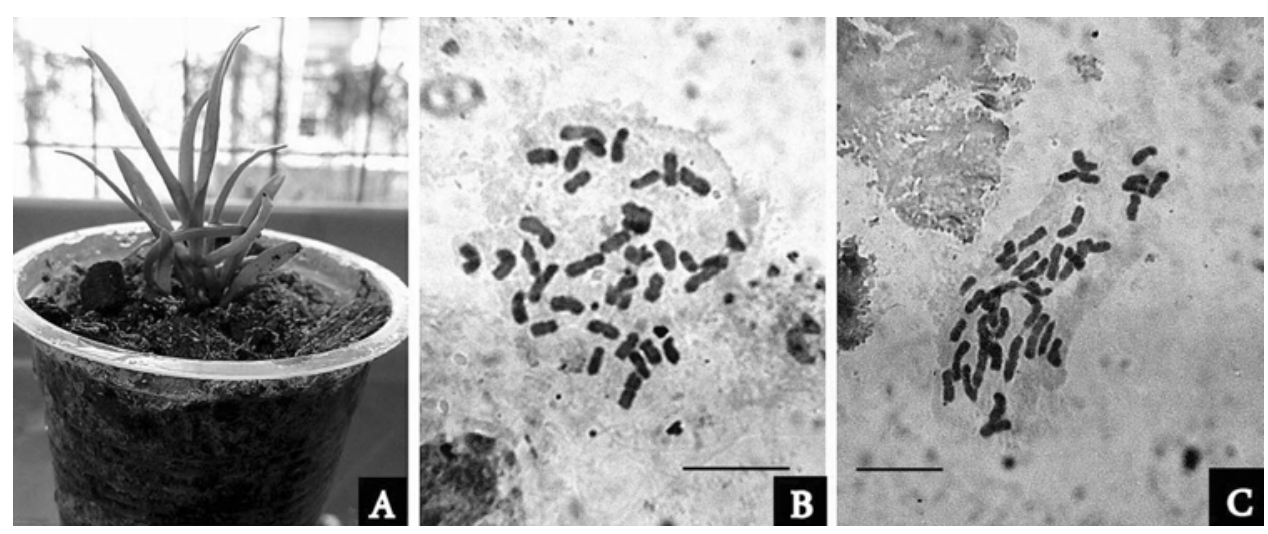

Fig. 2. Plantlets acclimation and its mitotic chromosome complement: A. Establishment of micropropagated plant in hardening mixture; $B \& C$. The normal diploid chromosome number of $2 n=38$ at mitotic metaphase in a somatic cell. Bar $=10 \mu \mathrm{m}$.

In this study, regeneration of plants via PLB formation was another pathway initiated from the shoot apices. For differentiation of PLBs, some orchid species do not require exogenous PGRs for PLB formation (Chen and Chang 2000, Roy and Banerjee 2003, Huan et al. 2004), while others are PGR-dependent (Lin et al. 2000, Lee and Lee 2003, Lu 2004, Wu et al. 2004). In the present study, even though PLB formation was quite efficient in the PGR free condition, the rate was further enhanced with the addition of BAP and NAA (Table 1). Histological observations of the responding explants showed the developing PLBs with vascular differentiation (Fig. 1C). Highest number of PLBs has been achieved in the medium containing NAA (2 mg/l). However, $1 \mathrm{mg} / \mathrm{l}$ NAA either individually or in combination with $1 \mathrm{mg} / \mathrm{l} \mathrm{BAP}$ showed moderate effect on the frequency of 
PLB formation (Table 1). This type of NAA efficacy of regeneration contradicts the previous reports in Bulbophyllum careyanum (Vij et al. 2000) and Dendrobium moschatum (Kanjilal et al. 1999). Number of PLBs was severely reduced in the medium containing $4 \mathrm{mg} / \mathrm{l} \mathrm{BAP}$. It is interesting to note that the frequency of PLB production in the presence of NAA alone was markedly reduced when increased level of BAP was added in this medium. This finding is in agreement with the results of Kalimuthu et al. (2007). In contrast, NAA has more or less no influence on the BAP activity regarding PLB production. PLB undergoes shoot and root differentiation for regeneration of the plantlets (Fig. 1E).

For induction of roots, the in vitro generated shootlets of D. pulcherrima were harvested and sub-cultured on $\mathrm{KC}+$ peptone basal medium as well as on the medium containing low levels of NAA. Regeneration of maximum number of roots was observed in PGR free medium suggesting that the $\mathrm{KC}+$ peptone medium alone is sufficient for root induction in this species. The medium containing NAA $(1-2 \mathrm{mg} / \mathrm{l})$, showed moderate root regeneration. On the contrary, the medium containing BAP either individually or in combination with NAA failed to generate any roots. This observation indicates that BAP has inhibitory effect on root induction. In the rooting medium, no morphological abnormalities, such as irregular leaf shape and color or abnormal root development were observed (Fig. 1F).

Further, somatic chromosome analysis from randomly selected root tips of in vitro regenerated plants and donor plants was carried out to assess the chromosomal stability during the in vitro multiplication of this species. Root tip cells of both in vitro regenerated and donor plants showed 38 chromosomes in somatic cells (Fig. 2B, C). Thus the present study reaffirms the chromosomal stability of the species during in vitro propagation.

The in vitro generated rooted plantlets of D. pulcherrima (Fig. 2A) were successfully hardened on a potting mixture containing small pieces of dead tree bark (mango), charcoal pieces and broken bricks in $1: 2: 1$ ratio. About $65 \%$ of the plantlets survived and initiated new growth. This piece of work suggests that broken charcoal and bricks are favorable material for the establishment of terrestrial orchids such as D. pulcherrima.

In summary, the present study describes two efficient morphogenetic pathways of in vitro propagation involving PLB formation and multiple axillary shoot regeneration in D. pulcherrima, using shoot tips as explants. The direct PLB formation without any intervening callus could be initiated best with $2 \mathrm{mg} / \mathrm{l}$ NAA. Hence the application of NAA at $2 \mathrm{mg} / \mathrm{l}$ is recommended for optimum PLB production. Second, axillary shoot regeneration could also be induced from shoot tips, for which 1 or $2 \mathrm{mg} / \mathrm{l}$ BAP could be used. The results reported here 
confirm the fact that the exogenous cytokinin is the most crucial growth regulator for the suppression of apical dominance (Kane 1996, Roy and Banerjee 2002), a process which leads to axillary shoot formation. The advantage of the second pathway is that shoot multiplication occurs through stimulation of axillary growth, which is the most preferred pathway for obtaining genetically stable plants (Kane 1996, Roy and Banerjee 2002). Furthermore, the genetic stability of the regenerated plants at chromosomal level has a direct relationship with the protocol system used. Thus the present protocol proves to be efficient and reproducible and can be used for large scale multiplication to fulfill the commercial demand of this valuable orchid species in orchid industry.

\section{Acknowledgements}

The authors express their sincere thanks to University Grants Commission, Bahadur Shah Zafar Marg, New Delhi, India for financial assistance.

\section{References}

Arditti J, Clement MA, Fast G, Hadley G, Nishimura G and Ernst R (1982) Orchid seed germination and seedling culture-a manual. In: Arditti J. (Ed.), Orchid Biology Reviews and Perspectives II. Cornell University Press, Ithaca and London, pp. 244370.

Arditti J and Ernst R (1993) Micropropagation of Orchids. J. Wiley and Sons Inc., New York. pp. 682.

Chen JT and Chang WC (2000) Efficient plant regeneration through somatic embryogenesis from callus cultures of Oncidium (Orchidaceae). Plant Sci. 160: 87-93

Christenson EA (1995) An overview of the genus Phalaenopsis. Orchid Digest, 59: 19-22.

Chugh S, Guha S and Rao U (2009) Micropropagation of orchids: A review on the potential of different explants. Sci. Hort. 122: 507-520.

Chung JD, Leu JH, Lee S and Kim CK (1998) Effect of medium composition on multiple shooting growth of mericlone from rhizome of shoot tip cultures of temperate Cymbidium species. In: Biological Abstract, 105(4): 50.

Devi JB, Borthakur B and Deka PC (1997) Clonal propagation of Dendrobium moschatum and Cymbidium aloifolium through shoot tip culture. J. Orchid Soc. India, 11: 19-21.

Ernst R (1994) Effects of thidiazuron on in vitro propagation of Phalaenopsis and Doritaenopsis (Orchidaceae). Plant Cell Tiss. Organ Cult. 39: 273-275.

Huan LVT and Tanaka M (2004) Callus induction from protocorm-like body segments and plant regeneration in Cymbidium (Orchidaceae). J. Hortic. Sci. Biotechnol. 79: 406410

Huang LC (1988) A procedure for asexual multiplication of Paphiopedilums in vitro. Am. Orchid Soc. Bull. 57: 274-278. 
Kalimuthu K, Senthikumar R and Murugalatha N (2006) Regeneration and mass multiplication of Vanilla planifolia Andr. - a tropical orchid. Curr. Sci. 91: 1401-1403.

Kalimuthu K, Senthilkumar R and Vijayakumar S (2007) In vitro micropropagation of orchid, Oncidium sp. (Dancing Dolls). Afr. J. Biotech. 6(10): 1171-1174.

Kane ME (1996) Propagation from preexisting meristems. - In: Trigiano R.N. and Gray D.J. (Ed.): Plant Tissue Culture Concepts and Laboratory Exercises. pp. 61-71, CRC Press, New York.

Kanjilal BD, Sarker DD, Mitra J and Datta KB (1999) Stem disc culture: Development of a rapid mass propagation method for Dendrobium moschatum (Buch. Ham.) Swartz.an endangered orchid. Curr. Sci. 77: 497-499.

Ket NV, Hahn EJ, Park SY, Chakrabarty D and Paek KY (2004) Micropropagation of an endangered orchid Anectochilus formosanus. Biol. Plant. 48: 339-344.

Lee YL and Lee N (2003) Plant regeneration from protocorm-derived callus of Cypripedium formosanum. In vitro Cell Dev. Biol. Plant 39: 475-479.

Lin YH, Chang C, Chang WC (2000) Plant regeneration from callus culture of a Paphiopedilum hybrid. Plant Cell Tiss. Organ Cult. 62: 21-25.

Lu MC (2004) High frequency plant regeneration from callus culture of Pleione formosana Hayata. Plant Cell Tiss. Organ Cult. 78: 93-96.

Morel G (1970) Neres ouf dem Gebiet der Meristem-Forchung. Die Orchidee, 20: 433-443.

Morel G (1974) Clonal multiplication of orchids. In: Withner C.L. (Ed.). The orchids: scientific studies. Wiley, New York.

Nagaraju V and Parthasarathy VS (1995) In vitro propagation of Phaius and bamboo orchid by shoot tip culture. Ann. Plant Physiol. 9: 102-104.

Pant B and Gurung R (2005) In vitro seed germination and seedling development in Aerides odorata Lour. J. Orchid Soc. India 19(1\&2): 51-55.

Rajkarnikar KM and Niraula R (1994) Tissue culture of Dendrobium fimbriatum for mass production. In Second National Botanical Conference, Dec. 23, Kath. Nepal. p. 34.

Roy J and Banerjee N (2002) Rhizome and shoot development during in vitro propagation of Geodorum densiflorum (Lam.) Schltr. Sci. Hort. 94: 181-192.

Roy J and Banerjee N (2003) Induction of callus and plant regeneration from shoot tip explants of Dendrobium fimbriatum Lindl. var. oculatum H.K. f. Sci. Hort. 97: 333-340.

Roy J, Naha S, Majumdar M and Banerjee N (2007) Direct and callus-mediated protocormlike body induction from shoot tips of Dendrobium chrysotoxum Lindl. Plant Cell Tiss. Organ Cult. 90: 31-39.

Seeni S and Latha PG (2000) In vitro multiplication and ecorehabilitation of the endangerd Blue Vanda. Plant Cell Tiss. Organ Cult. 61: 1-8.

Sherif NA, Benjamin JHF, Muthukrishnan S, Kumar TS and Rao MV (2012) Regeneration of plantlets from nodal and shoot tip explants of Anoectochilus elatus Lindley, an endangered terrestrial orchid. Afr. J. Biotechnol. 11(29): 7549-7553.

Subramaniam G and Taha RM (2003) Morphogenesis of Cymbidium atropurpureum in vitro. Malays. J. Sci. 22: 1-5.

Sunitibala H and Kishor R (2009) Micropropagation of Dendrobium transparens L. from axenic pseudobulb segments. Indian J. Biotechnol. 8: 448-452. 
Sweet HR (1980) The genus Phalaenopsis. California, Pomona: Day Printing Corporation.

Talukdar SK, Narsiruddin KM, Yasmin S, Hassan L and Begum R (2003) Shoot proliferation of Dendrobium orchid with BAP and NAA. J. Biol. Sci. 3(11): 1058-1062.

Teuscher H (1977) Collector's item: Phalaenopsis, Doritis and Kingidium. Am. orchid Soc. Bull. 46(3): 216-228.

Vendrame WA and Magnire I (2007) In vitro propagation and Plantlet Regeneration from Doritaenopsis Pruple Gem 'Ching Hua' Flower Explants. Hort. Sci. 42(5): 1256-1258.

Vij SP, Kher A and Pathak P (2000) Micropropagation of Bulbophyllum careyanum (Hook.) Spreng. using pseudobulb segments. J. Orchid Soc. India 14: 47-56.

Wu IF, Chen JT and Chang WC (2004) Effects of auxins and cytokinins on embryo formation from root-derived callus of Oncidium 'Gower Ramsey'. Plant Cell Tiss. Organ Cult. 77: 107-109. 